\title{
Apoptosis and Oxidative Stress Triggered by Carbon Black Nanoparticle in the LA-9 Fibroblast
}

\author{
Joice Margareth de Almeida Rodolpho ${ }^{a} \quad$ Krissia Franco de Godoy ${ }^{a}$ \\ Patrícia Brassolattia Bruna Dias de Lima Fragellia Cynthia Aparecida de Castro ${ }^{a}$ \\ Marcelo Assis ${ }^{b}$ Carlos Speglich ${ }^{c} \quad J u l i a n a$ Cancino-Bernardi ${ }^{d}$ Elson Longo ${ }^{b}$ \\ Fernanda de Freitas Anibala \\ aLaboratório de Inflamação e Doenças Infecciosas, Departamento de Morfologia e Patologia, \\ Universidade Federal de São Carlos, São Carlos, Brazil, 'bentro de Desenvolvimento de Materiais \\ Funcionais, Departamento de Química, Universidade Federal de São Carlos, São Carlos, Brazil, 'Centro \\ de Pesquisa Leopoldo Américo Miguez de Mello CENPES/Petrobrás, Rio de Janeiro, Brazil, 'aGrupo de \\ Nanomedicina e Nanotoxicologia, Instituto de Física de São Carlos, Universidade de São Paulo, São \\ Carlos, Brazil
}

\section{Key Words}

Apoptosis $\bullet$ Carbon black $\bullet$ Nanoparticle $\bullet$ Oxidative stress $\bullet$ ROS/RNS $\bullet$ Cell viability

\begin{abstract}
Background/Aims: A new type of nanoparticle, called NP CB-EDA (Black Carbon modified with ethylenediamine), is commonly used in the oil industry. In the literature, few studies are found in biological models, making NP-EDA potential cytotoxicity in organisms unclear. As its large surface area is capable of interacting with the biological system, that interaction could lead to factors harmful to health. The objective of this study was to investigate the cytotoxic effect of NP CB-EDA on fibroblasts LA-9 at 24 and 48 hours, at different concentrations of the nanoparticle (1, 50, 250, 500 and $1000 \mu \mathrm{g} / \mathrm{ml})$. Methods: NP CB-EDA was characterized by TEM microscopy and its effect on cell viability (MTT method), cell morphology (optical microscopy), cell membrane (lactate dehydrogenase release - LDH), oxidative stress pathways (species levels reactive oxygen, ROS and nitrogen, NOS) and apoptosis/necrosis (flow cytometry) were evaluated. Results: The results show that NP CB-EDA at concentrations of 500 and $1000 \mu \mathrm{g} /$ $\mathrm{ml}$ form clusters. The nanoparticle can be absorbed by cells decreasing cell viability. There was damage to the cell membrane of fibroblasts LA 9, an increase in the production of ROS, NOS and pro-inflammatory interleukins TNF- $\alpha$ and IL-6; it was also observed an increase in \% of cells in the state of apoptosis in the two periods analyzed, being this response more significant
\end{abstract}




\section{Cellular Physiology Cell Physiol Biochem 2021;55:364-377 \\ \begin{tabular}{ll|l} 
DOl: $10.33594 / 000000382$ & $\begin{array}{l}\text { O } 2021 \text { The Author(s). Published by } \\
\text { Cell Physiol Biochem Press GmbH\&Co. }\end{array}$ \\
\hline
\end{tabular} \\ de Almeida Rodolpho et al.: Apoptosis and Oxidative Stress Triggered by Carbon Black \\ Nanoparticle}

in 24 hours, and concentrations of 250, 500 and $1000 \mu \mathrm{g} / \mathrm{ml}$ presenting higher cytotoxicity. Conclusion: The data suggest that NP CB-EDA in fibroblasts LA9 presents cytotoxic potential, which is associated with oxidative stress and apoptosis.

(C) 2021 The Author(s). Published by Cell Physiol Biochem Press GmbH\&Co. KG

\section{Introduction}

Nanostructured materials are widely used in several industrial sectors. Among them is Carbon Black (CB), with applications in the fields of nanotechnology, oil exploration and reservoir characterization, in addition to use in medicine, catalysis and environmental remediation [1].

To facilitate the interaction of the surface of the nanoparticle (NP) with the medium and to improve their dispensability and compatibility, CB can be bonded to covalent polymers; for that its surface is sequentially modified with ethylenediamine (EDA) generating the nanoparticle called CB-EDA [2]. This modification with EDA can completely alter the biological activity of NP, as it is a combination of modified physical-chemical properties, making CB-EDA a substance with toxic potential [3].

However, few studies are found in the literature in biological models with the NP CBEDA that discuss its application and if the use can be potentially harmful, since its large surface area can interact with different biological systems. Thus, considering the variety of applications and the potential exposure of workers and consumers to this NP, it is of fundamental importance to assess the risks of its cytotoxicity [4].

This leads to the urgent need to understand how NP CB-EDA acts in biological systems, through in vitro/in vivo analysis, seeking to understand how oxidative pathways, such as the production of reactive oxygen species (ROS) and reactive nitrogen species (NOS), are related to synthesis and release of pro-inflammatory molecules, such as TNF-alpha, generating cell death by apoptosis with release of death markers, such as membrane enzymes and reduction of cytotoxicity [5-13].

Thus, it is necessary to evaluate the cytotoxic effects of NP CB-EDA in biological models. Therefore, the aim of this study is to elucidate mechanisms responsible for cytotoxicity in fibroblast cells lineage LA-9, after exposure to NP CB-EDA, to clarify the relationships between inflammation, oxidative stress production and apoptosis.

\section{Materials and Methods}

\section{Nanoparticle}

The NP CB-EDA was provided by the petroleum industry Centro de Pesquisa Leopoldo Américo Miguez de Mello CENPES/Petrobrás, Rio de Janeiro, RJ, Brazil. PETROBRAS. The experimental design is illustrated in Supplementary Fig. 1 (for all supplementary material see www.cellphysiolbiochem.com).

\section{Characterization}

The morphological and size features of NP CB-EDA samples was examined by transmission electron microscopy TEM, and high-resolution TEM (HR-TEM) micrographs were performed with a FEI TECNAI F20 (Netherlands) microscope operating at $200 \mathrm{kV}$. The zeta potential of the NP CB-EDA suspended in water, DMEM and DMEM + 10\% was evaluated using a Malvern spectrometer Nano-ZS (Marvern Instruments). The results are presented as mean \pm SD resulting from three different measurements.

\section{Fibroblasts LA9 culture}

Fibroblasts of the LA9 lineage of mouse adipose connective tissue from the cell bank of Rio de Janeiro (BCRJ), code 0142, were used. Cultivation occurred in bottles containing Dulbecco's Modified Eagle's Medium (DMEM, Sigma) supplemented with $10 \%$ fetal bovine serum (LGC Biotechnology) at $37^{\circ} \mathrm{C}$ and with $5 \% \mathrm{CO}_{2}$. A protocol was established with 3 independent experiments in biological triplicate with the following concentrations of the NP CB-EDA modified with ethylenediamine (NP CB-EDA): 1, 50, 250500 and $1000 \mu \mathrm{g} / \mathrm{mL}$, for 24 and 48 hours. 


\section{Cellular Physiology Cell Physiol Biochem 2021;55:364-377 \\ \begin{tabular}{l|l|l} 
and Biol: 10.33594/000000382 & (c)21 The Author(s). Published by
\end{tabular} \\ and BIOChemistry $\frac{\text { Published online: } 26 \text { June } 2021 \quad \text { Cell Physiol Biochem Press GmbH\&Co. KG }}{\text { de Almeida Rodolpho et al.: Apoptosis and Oxidative Stress Triggered by Carbon Black }}$ \\ Nanoparticle}

Cytotoxicity assay with MTT and $E C_{50}$

The cytotoxic activity of NP CB-EDA was evaluated using the MTT colorimetric assay (MTT [3-(4,5-dimethylthiazol-2-yl)-2,5-diphenylthetrazolium bromide] -Sigma-Aldrich, USA) (MOSMANN, 1983). Initially, a preliminary test was performed to determine which concentrations of NP CB-EDA would be included in subsequent tests, based on the literature, that reported the most studied concentrations for nanoparticles vary from 1 to $1000 \mu \mathrm{g} / \mathrm{ml}[5,6]$. The concentrations of 1, 50, 250, 500 and $1000 \mu \mathrm{g} / \mathrm{ml}$ were chosen to carry out the study. In a 96-well plate $6 \times 10^{3}$ cells/well were seeded. After 24 hours for cell adhesion, concentrations of NP CB-EDA were applied. After the exposure time (24 and 48 hours) a $5 \mathrm{mg}$ / mL MTT solution was added to each well and the reaction occurred for 4 hours. In $100 \mu \mathrm{L}$ of DMSO the formazan crystals produced were solubilized and the absorbance was measured at $570 \mathrm{~nm}$ on the plate spectrophotometer (Thermo Scientific ${ }^{\mathrm{TM}}$ Multiskan $^{\mathrm{TM}}$ GO Microplate Spectrophotometer). The absorbance values were used to calculate the $\mathrm{EC}_{50}$ (concentration that induces half the effect) and cell viability (\% of cytotoxicity $=$ absorbance of the test groups $\mathrm{x} 100 /$ absorbance of the control group). The percentage of cell viability occurred by comparing the data obtained with the control group according to the equation below:

$$
\% \text { cytotoxicity }=\frac{\text { Experimental group } \mathrm{x} 100}{\text { Average control }}
$$

\section{Detection of reactive nitrogen species (RNS)}

Nitric oxide (NO) production was evaluated using the Griess reaction $[14,15]$. In a 96-well plate $1 \times 10^{4}$ cells/well were cultured. After 24 hours for cell adhesion, concentrations 1, 50, 250500 and $1000 \mu \mathrm{g} / \mathrm{mL}$ of NP CB-EDA were applied. After the exposure times ( 24 and 48 hours), the supernatant was collected, then $50 \mu \mathrm{L}$ were added to a new 96-well plate; $50 \mu \mathrm{L}$ of the Griess reagent (1: 1 mixture of solution A [ $1 \%$ sulfanilamide in $5 \%$ phosphoric acid) and $50 \mu \mathrm{L}$ of solution B [0.1\% N-1-naphthylethylenediamine dihydrochloride]) were added followed by incubation for 15 minutes. The absorbance was measured at 540 $\mathrm{nm}$ on the plate spectrophotometer (Thermo Scientific ${ }^{\mathrm{TM}}$ Multiskan $^{\mathrm{TM}}$ GO Microplate Spectrophotometer). A standard curve was constructed with sodium nitrite.

\section{Quantification of IL-6 and TNF- $\alpha$ cytokines}

The levels of cytokines IL- 6 and TNF- $\alpha$ were measured using the ELISA quantification kit (BD Biosciences). In a 96-well plate $1 \times 10^{4}$ cells/well were cultured. After 24 hours for cell adhesion, concentrations 1, 50, 250500 and $1000 \mu \mathrm{g} / \mathrm{mL}$ of NP CB-EDA were applied. After the exposure time (24 and 48 hours), the pool of supernatant from each group was collected and $50 \mu \mathrm{L}$ was added to a new 96-well plate for ELISA. The absorbance was read at $450 \mathrm{~nm}$ on the plate spectrophotometer (Thermo Scientific ${ }^{\mathrm{Tm}}$ Multiskan $^{\text {TM }}$ GO Microplate Spectrophotometer). The cytokine concentrations produced were calculated using a standard kit curve for each sample.

\section{LDH (Lactate dehydrogenase)}

Cytotoxicity damage to the cell membrane was assessed by measuring LDH production according to the CyQuant ${ }^{T M}$ LDH Cytotoxicity Assay Kit (Invitrogen). In a 96-well plate $1 \times 10^{4}$ cells/well were seeded. After 24 hours for cell adhesion, concentrations of NP CB-EDA were applied. After the exposure times (24 and 48 hours), the supernatant from each group was collected and $50 \mu \mathrm{L}$ was added to a new 96 -well plate. The reagent solution $50 \mu \mathrm{L}$ was added to each well for 30 minutes. The absorbance was read at $490 \mathrm{~nm}$ and 680 $\mathrm{nm}$ on the plate spectrophotometer (Thermo Scientific ${ }^{\mathrm{TM}}$ Multiskan $^{\mathrm{TM}} \mathrm{GO}$ Microplate Spectrophotometer). To determine LDH activity, the values obtained at $680 \mathrm{~nm}$ from $490 \mathrm{~nm}$ were subtracted and the $\%$ cytotoxicity was calculated using the formula:

$$
\% \text { cytotoxicity }=\frac{\text { (Experimental group-spontaneous LDH activity) } \times 100}{\text { (Maximum LDH activity-spontaneous LDH activity) }}
$$

The wells of spontaneous LDH activity contained $10 \mu \mathrm{L}$ of water and the maximum LDH activity contained $10 \mu \mathrm{L}$ of lysis solution. 


\section{Cellular Physiology Cell Physiol Biochem 2021;55:364-377 \\ \begin{tabular}{l|l} 
and Bincl $10.33594 / 000000382$ & 2021 The Author(s). Published by
\end{tabular} \\ Published online: 26 June $2021 \quad$ Cell Physiol Biochem Press GmbH\&Co. KG \\ de Almeida Rodolpho et al.: Apoptosis and Oxidative Stress Triggered by Carbon Black \\ Nanoparticle}

Detection of reactive oxygen species (ROS)

The production of reactive oxygen species (ROS) was measured using the fluorescent probe DCFH-DA $\left(2^{\prime}, 7^{\prime}\right.$-Dichlorodihydrofluorescein Diacetate) (Sigma-Aldrich) [16]. In a 96-well plate $1 \times 10^{4}$ cells/well were cultured. After 24 hours for cell adhesion, concentrations of NP CB-EDA were applied. After the exposure times ( 24 and 48 hours), the DCFH-DA probe diluted in medium for 30 minutes was applied to each well. The wells were washed with PBS $1 \mathrm{X}$ and the fluorescence emission was read at 485-530 nm on the Spectra MAX i3 $₫$ plate spectrophotometer (Molecular Devices). The values obtained were transformed into percentages using the same formula previously mentioned in the MTT test.

\section{Clonogenic assay}

The capacity of fibroblasts LA 9 to recover (forming colonies) after exposure to NP CB-EDA was assessed using the clonogenic assay [17]. In a 6-well plate 1000 cells/well were cultured. After 24 hours for cell adhesion, concentrations of NP CB-EDA were applied. After the exposure times ( 24 and 48 hours) the supernatant was removed and discarded and culture medium was added $(1 \mathrm{~mL})$. After 7 days of recovery, the cells were fixed with methanol and stained with $0.1 \%$ violet crystal. The wells were photographed and using the ImageJ 1.53a software [18] colony counts were made. The absorbance reading was measured at $570 \mathrm{~nm}$ in a plate spectrophotometer (Thermo Scientific ${ }^{\mathrm{TM}}$ Multiskan $^{\mathrm{TM}}$ GO Microplate Spectrophotometer).

\section{Cell morphology}

Fibroblasts LA9 morphology was evaluated after exposure to different concentrations of NP CB-EDA. In a 96-well plate $1 \times 10^{4}$ cells/well were seeded. After 24 hours for cell adhesion, concentrations of NP CBEDA were applied. After the exposure times ( 24 and 48 hours), the cell morphology was observed in an optical microscope Axiovert $40 \mathrm{CFL}$ (Zeiss), which images were captured using the coupled camera model LOD-3000 (Bio Focus) and analyzed by software Future WinJoe TM version 2.0.

\section{Cell death by apoptosis/ necrosis using the Annexin V marker}

Cell death by apoptosis and necrosis was assessed with the annexin $\mathrm{V}$ marker using the BD Biosciences detection kit. In a 24-well plate $1 \times 10^{5}$ cells/well were cultured. After 24 hours for cell adhesion, concentrations of NP CB-EDA were applied. After the exposure times (24 and 48 hours), the plates were centrifuged and washed; then PE Annexin V and 7AAd antibodies ( $1 \mu \mathrm{l} /$ well in binding buffer) were added. The reaction took place for 15 minutes. An Accuri ${ }^{\mathrm{TM}} \mathrm{C} 6 \mathrm{BD}$ Biosciences flow cytometer was used for analysis (gate 10.000 events). Data analysis was made using the software flowJo 10.7.1 (BD Biosciences).

\section{Cell death by apoptosis/necrosis with Acridine Orange and Propidium Iodide}

Cell death by apoptosis or necrosis was analyzed through an image stained with Acridine Orange (LA) and Propidium Iodide (IP). In a 96-well plate $1 \times 10^{4}$ cells/well were cultured. After 24 hours for cell adhesion, concentrations of NP CB-EDA were applied. After the exposure times (24 and 48 hours), the supernatant from the wells was removed and $30 \mu \mathrm{L}$ of LA/IP $0.1 \%$ (1:1) pigment were added to each well for 15 minutes. Then the wells were washed and medium was added $(1 \mathrm{~mL})$. The images were obtained using an automated high-resolution epifluorescent microscopy system ImageXpress Micro (Molecular Devices) with a 40-x objective lens and FITC and Texas Red filters with image overlay.

\section{Statistical analysis}

The results were analyzed using GraphPad Prism 7.0 (San Diego, California, USA) and Sigmaplot software (version 14). The identification of the discrepant data was performed through the Grubbs analysis, followed by the distribution of variables tested using the normality (Shapiro-Wilk test) and equal variance (Levene method). For the analysis of multiple comparisons, Two-way ANOVA with Tukey post hoc tests were used to evaluate the variance between groups for parametric data (results were presented in mean and standard deviation) and nonparametric data, the Kruskal-Wallis test was used with post hoc Dunn (results were presented as the median with the upper and lower quartiles: Me [Q1; Q3]). The statistical significance established was $\mathrm{p}<0.05$. 


\section{Cellular Physiology Cell Physiol Biochem 2021;55:364-377 \begin{tabular}{ll} 
and Biochemistry & $\begin{array}{l}\text { DOI: } 10.33594 / 000000382 \\
\text { Published online: } 26 \text { June } 2021\end{array}$ \\
\hline
\end{tabular} \\ de Almeida Rodolpho et al.: Apoptosis and Oxidative Stress Triggered by Carbon Black Nanoparticle}

\section{Results}

The analysis of TEM was performed to observe the size of pure CB-EDA nanoparticles, CBEDA $500 \mu \mathrm{g} / \mathrm{ml}$ and CB-EDA $1000 \mu \mathrm{g} / \mathrm{ml}$, as well as their profile of agglomeration, according to the increase of their concentration in the culture medium (Fig. 1). It was observed for all samples that there is no change in the size of the individual CB particles, which vary between 13 and $68 \mathrm{~nm}$, with an average size of $48 \mathrm{~nm}$. However, the increase in the concentration of CB nanoparticles in the culture medium causes them to start to agglomerate, generating dense regions in specific areas (Fig. 1B, C). The interaction of CB nanoparticles with the culture medium causes the formation of protein corona on their surfaces, which can change not only intrinsic characteristics of the nanoparticles, but also their available surface area. [19, 20]. This happens because of the change in the surface charge of the CB nanoparticles in the culture medium, which becomes more positive, due to the presence of multivalent cations that are a constituent part of the cell culture medium used [11]. The surface charge of NPCBEDA dispersed in different medium was compared by zeta potential measurements. The zeta potential of the NP CB-EDA in water was approximately $-13.3 \pm 1.59 \mathrm{mV}$, revealing a negative charged nanoparticle due to the presence of carboxyl groups at their surface. Zeta potential of CB-EDA in culture medium further confirmed the decrease of their negative charge due to the corona protein formation. The zeta potential of CB-EDA changed from highly negative to $-12.5 \pm 1.05 \mathrm{mV}$ in DMEM and $-9.21 \pm 1.24 \mathrm{mV}$ in DMEM + 10\% FBS.

Fig. $2 \mathrm{~A}$ and $\mathrm{B}$ shows the cell viability and $\mathrm{EC}_{50}$ of fibroblasts LA- 9 after 24 and 48 hours of exposure to CB-EDA NP in the groups control, 1, 50, 250, 500 and $1000 \mu \mathrm{g} / \mathrm{ml}$. Cell viability decreased significantly in 24 hours in the groups exposed to $250 \mu \mathrm{g} / \mathrm{ml}, 500 \mu \mathrm{g} / \mathrm{ml}$ and $1000 \mu \mathrm{g} / \mathrm{ml}$ of CB-EDA NP, when compared to the control group, and in 48 hours in the groups exposed to $250 \mu \mathrm{g} / \mathrm{ml}, 500 \mu \mathrm{g} / \mathrm{ml}$ and $1000 \mu \mathrm{g} / \mathrm{ml}$ of CB-EDA NP, when compared to the control group. There was no significant difference between the two periods (Fig. 2A). $\mathrm{EC}_{50}$ was calculated according to each concentration and each stimulated time of exposure is shown in (Fig. 2B). In 24 hours the $\mathrm{EC}_{50}$ was $16.19 \mu \mathrm{L}$, and in 48 hours it was $133.9 \mu \mathrm{L}$.

The rupture of the membrane is shown on the LDH assay at 24 and 48 hours, after exposure of different concentrations of NP CB-EDA (1, 50, 250, 500 and $1000 \mu \mathrm{g} / \mathrm{ml}$ ) in fibroblasts LA9 (Fig. 2C). The data shows that there was a significant difference in 24 hours in the group exposed to $1000 \mu \mathrm{g} / \mathrm{ml}$ when compared to the control group. Within 48 hours there was a significant difference in the concentrations of $50 \mu \mathrm{g} / \mathrm{ml}$ and $1000 \mu \mathrm{g} / \mathrm{ml}$, when compared to the control group.

In Fig. 2D, it is observed the colony formation test (clonogenic assay) of the control group and the groups exposed to NP CB-EDA 1.50, 250, 500 and $1000 \mu \mathrm{g} / \mathrm{ml}$ in 24 and 48 hours. The decrease in the number of colonies was observed both in 24 and 48 hours at concentrations of 250, 500 and $1000 \mu \mathrm{g} / \mathrm{ml}$ of the NP CB-EDA, when compared with the

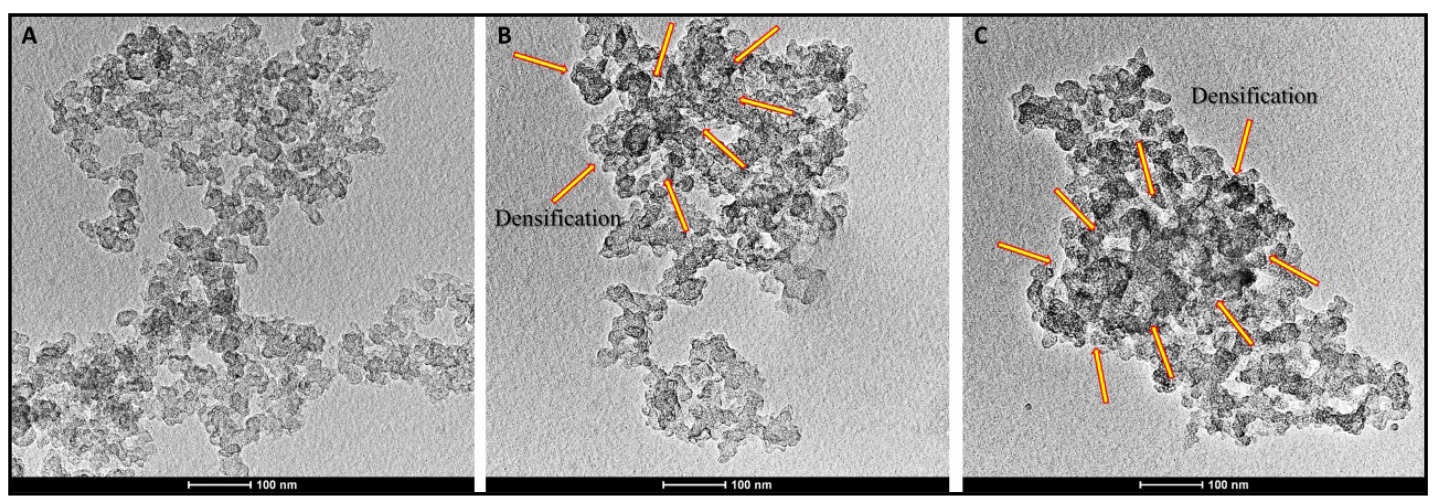

Fig. 1. Characterization of NP CB-EDA: TEM images of NP CB-EDA in Dmen medium: A) pure CB-EDA, B) CB-EDA $500 \mu \mathrm{g} / \mathrm{mL}$ and C) CB-EDA $1000 \mu \mathrm{g} / \mathrm{mL}$ samples. 
de Almeida Rodolpho et al.: Apoptosis and Oxidative Stress Triggered by Carbon Black

Nanoparticle

control group (Fig. 2E). The concentrations of 500 and $1000 \mu \mathrm{g} / \mathrm{ml}$ showed similar number of colonies compared to the control group (Fig, 2F). As a non-colorimetric test, it helps to certify the feasibility of the other tests performed.

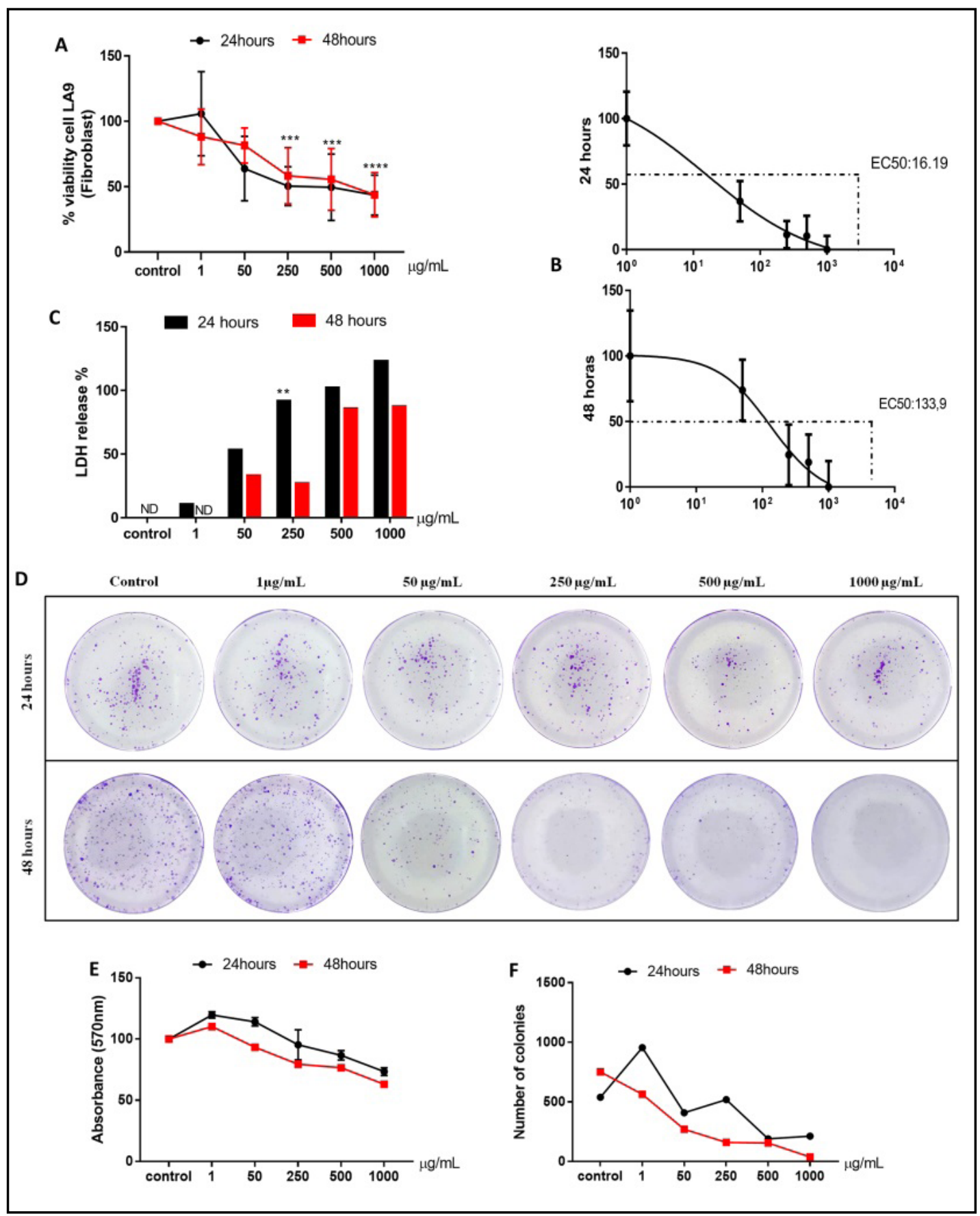

Fig. 2. Cell viability via MTT assay and EC50, LDH release and cell morphology. Viability cell: MTT (A and B) and EC50 and LDH (C). Data are shown at 24 hours (in black) and 48 hours (in red) in the control groups and exposed to concentrations of 1, 50, 250, 500 and $1000 \mu \mathrm{g} / \mathrm{mL}$ of NP CB-EDA. (D) the formation the colonies of fibroblasts cells after 7 days of recovery after 24 hours of exposure of NP CB-EDA. (E) Quantification of absorbance of recovered colonies represented in percentage (F) number of colonies (qualitative data). * ( $p<0.05)$ vs Control in 24 hours. \& $(\mathrm{p}<0.05)$ vs Control in 48 hours. ND (not detected). 


\section{Cellular Physiology Cell Physiol Biochem 2021;55:364-377 \\ \begin{tabular}{ll} 
and Biochemistry & $\begin{array}{l}\text { DOI: } 10.33594 / 000000382 \\
\text { Published online: } 26 \text { June } 2021\end{array}$ \\
\hline
\end{tabular} \\ de Almeida Rodolpho et al.: Apoptosis and Oxidative Stress Triggered by Carbon Black \\ Nanoparticle}

Fig. 3A shows the morphology of the fibroblasts LA-9 after exposure to NP CB-EDA in the groups control, 1, 50, 250, 500 and $1000 \mu \mathrm{g} / \mathrm{ml}$. It is possible to observe in the images a decrease in the size and in the number of the cells in 24 hours as in 48 hours in the groups treated with $250 \mathrm{ug} / \mathrm{mL}, 500 \mathrm{ug} / \mathrm{mL}$ and $1000 \mu \mathrm{g} / \mathrm{ml}$, when compared to the control group. (Fig. 3A).

Fig. $4 \mathrm{~A}$ shows the production of NO detected by the Griss reaction after exposure of different concentrations of NP CB-EDA $(1,50,250,500$ and $1000 \mu \mathrm{g} / \mathrm{ml})$, with a significant difference in the period of 24 hours, when the cells were exposed to concentrations of 500 $\mu \mathrm{g} / \mathrm{ml}$ and $1000 \mu \mathrm{g} / \mathrm{ml}$; it was possible to observe an increase in the production of NO in both concentrations when compared to control. In the 48 hours period, there is a significant difference when the cells were exposed to concentrations of $500 \mu \mathrm{g} / \mathrm{ml}$, where it was possible to observe an increase in the production of NO in both concentrations.

Fig. 4B shows the production of reactive oxygen species (ROS) in the control group and in the groups exposure to 1, 50, 250, 500 and $1000 \mu \mathrm{g} / \mathrm{ml}$ of NP CB -EDA, after 24 and 48 hours, assessed by fluorescence measurement using the DCF-DA probe. Significant difference in the increase in ROS was observed at concentrations of $250 \mu \mathrm{g} / \mathrm{ml}$ and $1000 \mu \mathrm{g} / \mathrm{ml}$, when compared to the control, in the 24 hours exposure period. Regarding the evaluation of the 48 hours period, there is a significant difference in the concentrations of $250 \mu \mathrm{g} / \mathrm{ml}$ and $1000 \mu \mathrm{g} / \mathrm{ml}$.

The expression of TNF- $\alpha$ and IL- 6 cytokines is shown in Fig. 4C and D. No detection was found within 24 hours. In the 48 hours exposure period, despite the expression of TNF- $\alpha$ being present in all evaluated groups, no statistically significant difference was found comparing with the control.

Cell death by apoptosis/necrosis was illustrated using the Dot Plot graph after 24 hours (Fig. 5A) and 48 hours (Fig. 5B), in the control group and the groups exposed to 1, 50, 250, 500 and $1000 \mu \mathrm{g} / \mathrm{ml}$ of NP CB -EDA in fibroblasts LA9. Each marker is expressed by \% fluorescence. The marker 7AAD in the $\mathrm{X}$ axis, represents necrosis, and PE Annexin $\mathrm{V}$ in the $\mathrm{y}$ axis, represents apoptosis.

The Dot Plot graph is represented by the upper left quadrant (Q1), in which are the cells marked with 7AAD and in a state of necrosis. In the lower right quadrant (Q3) are the cells marked with Annexin V (PE) and in an initial apoptosis state. In the upper right quadrant (Q2) are the double positive cells, that are marked with both PE and 7AAD, showing late apoptosis. Living cells are represented in the lower left quadrant (Q4). Fig. 5C and D shows the fluorescence emission peaks of the Anexin PE and 7AAD markers, representing apoptosis and necrosis in fibroblasts LA-9, after 24 and 48 hours of exposure to NP CB-EDA. Each emission peak represents a group differentiated by color.

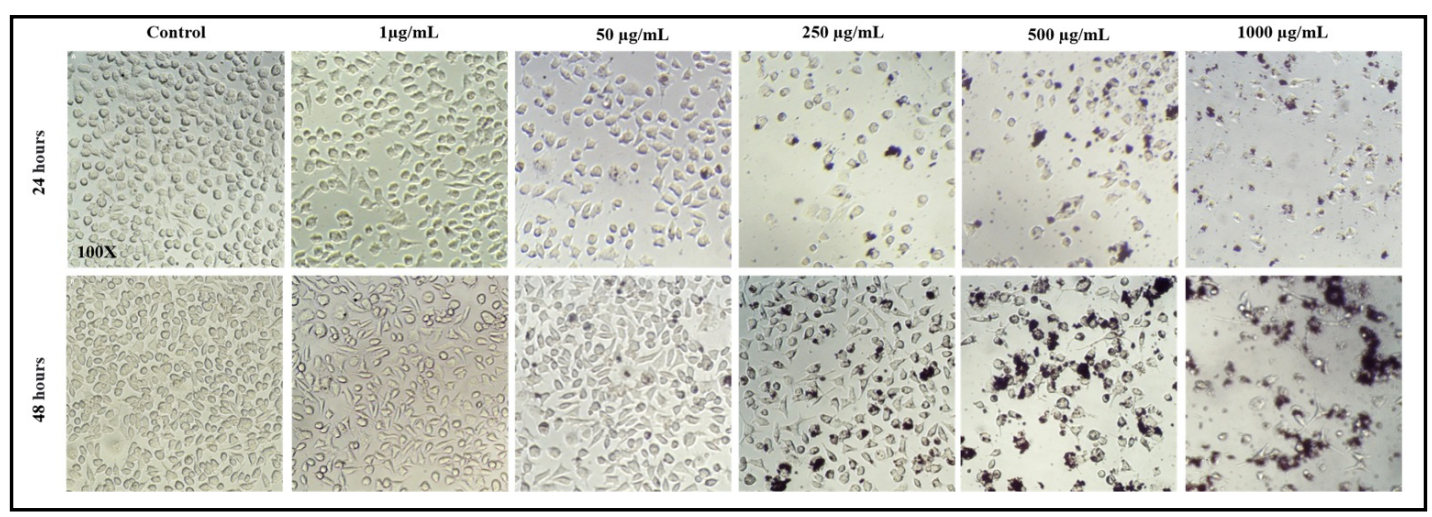

Fig. 3. Cell morphology: Cell morphology is represented by optical microscopy images with a total increase of $100 \mathrm{x}$, in the control groups and exposed to concentrations of $1,50,250,500$, and $1000 \mu \mathrm{g} / \mathrm{mL}$ of NP CBEDA: (A) $24 \mathrm{~h}$; (B) $48 \mathrm{~h}$. 


\section{Cellular Physiology Cell Physiol Biochem 2021;55:364-377 \begin{tabular}{ll|l} 
& DOl: 10.33594/000000382 & $\begin{array}{l}\text { O } 2021 \text { The Author(s). Published by } \\
\text { Cell Physiol Biochem Press GmbH\&Co. KG }\end{array}$ \\
\cline { 2 - 3 }
\end{tabular} \\ de Almeida Rodolpho et al.: Apoptosis and Oxidative Stress Triggered by Carbon Black Nanoparticle}

Fig. 4. ROS / RNS oxidative stress pathway and TNF- $\alpha$ and IL-6 pro-inflammatory markers. (A) NO production in LA9 fibroblasts after exposure to different levels of NP CB-EDA (1; 50; 250; 500; and $1000 \mu \mathrm{g} / \mathrm{mL}$ ) and Control (cells + medium) in the periods of 24 and 48 hours. (B) Production of ROS in LA9 fibroblasts after 24 and 48 hours of exposure to NP CB-EDA. Cells exposed to 1 ; 50 ; 250; 500 and $1000 \mu \mathrm{g} / \mathrm{mL}$, Control (cells + medium).

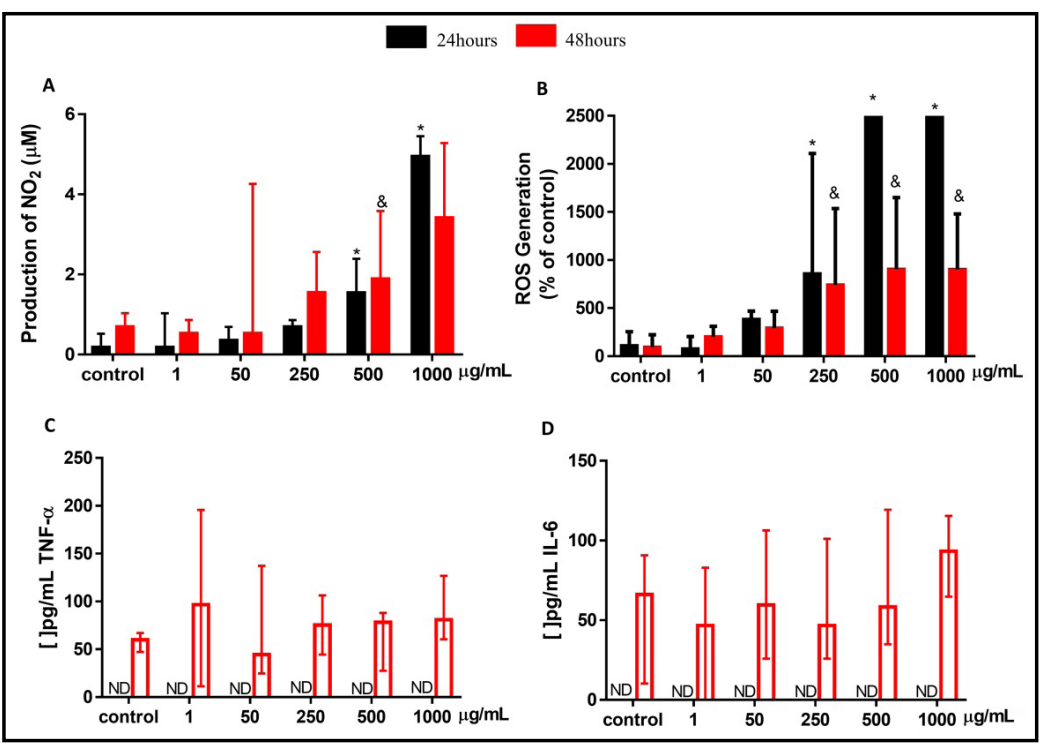
The results show both the comparison of the concen-

trations evaluated in relation to the control and the comparison of the groups in relation to the time of exposure (24 and 48 hours), (C) Production of IL-6 cytokines after exposure of NP CB-EDA in LA-9 fibroblasts for 24 and 48 hours, (D) TNF- $\alpha$ cytokine production after exposure of NP CB-EDA to LA-9 fibroblasts for 24 and 48 hours. ${ }^{*} \mathrm{p}<0.05$ and vs Control $24 \mathrm{~h} . \& \mathrm{p}<0.05 \mathrm{vs} 48 \mathrm{~h}$ Control.

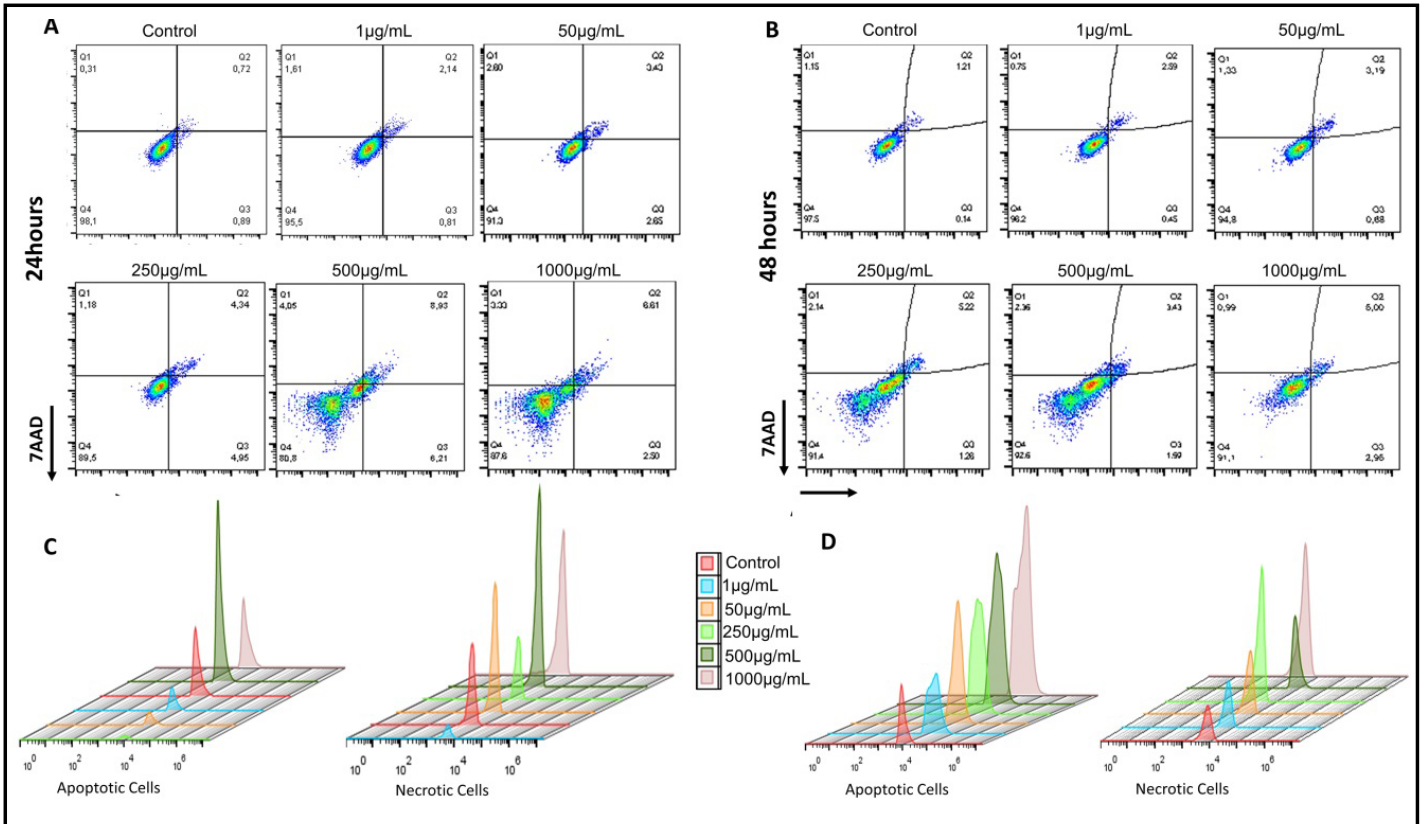

Fig. 5. Flow cytometry for analysis of cell death due to apoptosis / necrosis in LA-9 fibroblasts. (A, B). LA-9 cells were exposed to the following concentrations of NP CB-EDA 1, 50, 250, 500 and $1000 \mu \mathrm{g} / \mathrm{mL}$ and analyzed for the percentage of necrotic or apoptotic cells. (C, D). Histogram graph represents each peak of fluorescence emission in the control group (red) and in the groups exposed to 1(blue), 50 (orange), 250 (light green), 500 (dark green) and $1000 \mu \mathrm{g} / \mathrm{mL}$ (lilac), NP CB-EDA after 24 and 48 hours. 


\section{Cellular Physiology and Biochemistry}

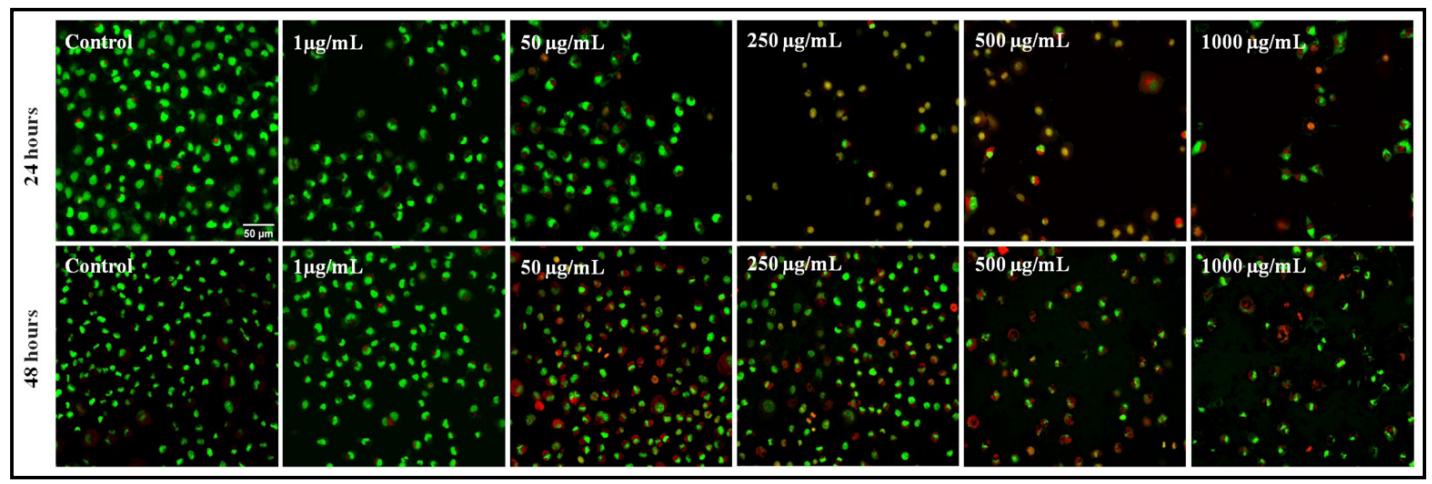

Fig. 6. Images of apoptosis / necrosis in LA-9 Fibroblast: High resolution fluorescence images to demonstrate LA- 9 cells undergoing apoptosis/necrosis cell death 24 and 48 hours after treatment with NP CB-EDA in the control group and in the groups exposed to 1, 50, 250, 500 and $1000 \mu \mathrm{g} / \mathrm{ml}$. Images obtained using an automated high resolution epifluorescent microscopy system with LA and IP fluorophores.

Fig. 6A shows high resolution epifluorescent microscopy images of fibroblasts LA-9, after 24 and 48 hours of exposure to different concentrations 1, 50, 250, 500 and $1000 \mu \mathrm{L} / \mathrm{mL}$ of NP CB-EDA, and stained with acridine orange, which marks living and dead cells and emits green, and with propidium iodide that marks dead cells, in which the reddish cytoplasm indicates initial apoptosis, and the reddish nucleus indicates late apoptosis and necrosis. The overlapping of images shows that the groups control, $1 \mathrm{ug} / \mathrm{mL}$ and $50 \mu \mathrm{g} / \mathrm{mL}$ in 24 hours, and control in 48 hours do not present cellular damage, with preserved morphology, green color and high number of cells. The other groups have altered morphology, decreased number of orange cells and nucleus showing late apoptosis and necrosis, both in 24 and 48 hours.

Fig. 7A and D shows the \% of each apoptosis/necrosis marker after 24 and 48 hours of exposure to NP CB-EDA, according to each concentration analyzed. The necrotic cells are represented in Fig. 5A, in which, within 24 hours, showed a significant increase in cell \% in the group exposed to $500 \mu \mathrm{g} / \mathrm{ml}$, when compared with the control group. After 48 hours, there was a significant increase in the $\%$ of cells exposed to 50 and $1000 \mu \mathrm{g} / \mathrm{ml}$.

Apoptotic cells are represented in Fig. 7D. After 24 hours, there was a significant increase in the $\%$ of apoptotic cells in the groups exposed to 50, 250, 500 and $1000 \mu \mathrm{g} / \mathrm{ml}$ of NP CBEDA, when compared to the control group. In 48 hours, there was a significant increase in the $\%$ of apoptotic cells in the groups exposed to 250,500 and $1000 \mu \mathrm{g} / \mathrm{ml}$ of NP CB-EDA.

Fig. $7 \mathrm{~B}$ and $\mathrm{C}$ show the heatmap graph with the comparison between the average number of cells. Fig. 7B shows the comparison between necrotic cells between the 24 and 48 hours. Fig. 7C represents the comparison of apoptotic cells between the periods of 24 and 48 hours. Such comparisons make it possible to understand which group has more apoptotic/necrotic cells, where the green color represents the minimum and the red color the maximum value obtained. Representative scheme of the results can be found in the Supplementary Fig. 2.

\section{Discussion}

This study was designed to elucidate the biological effect of the CB-EDA nanoparticle in fibroblasts LA-9, the impact of this effect on the pathways of apoptosis / necrosis, oxidative stress, and inflammation, at 24 and 48 hours. The size of the NP CB-EDA was confirmed by transmission electron microscopy (TEM) at 13 and $68 \mathrm{~nm}$, with an average size of 48 $\mathrm{nm}$. However, it was observed that increasing concentration in the culture medium leads to agglomeration and densification rate of the, NP CB-EDA at $1000 \mu \mathrm{g} / \mathrm{ml} \mathrm{sample.} \mathrm{Since} \mathrm{the}$ rate of agglomeration, as well as the interaction of carbon nanoparticle with the culture 
de Almeida Rodolpho et al.: Apoptosis and Oxidative Stress Triggered by Carbon Black Nanoparticle

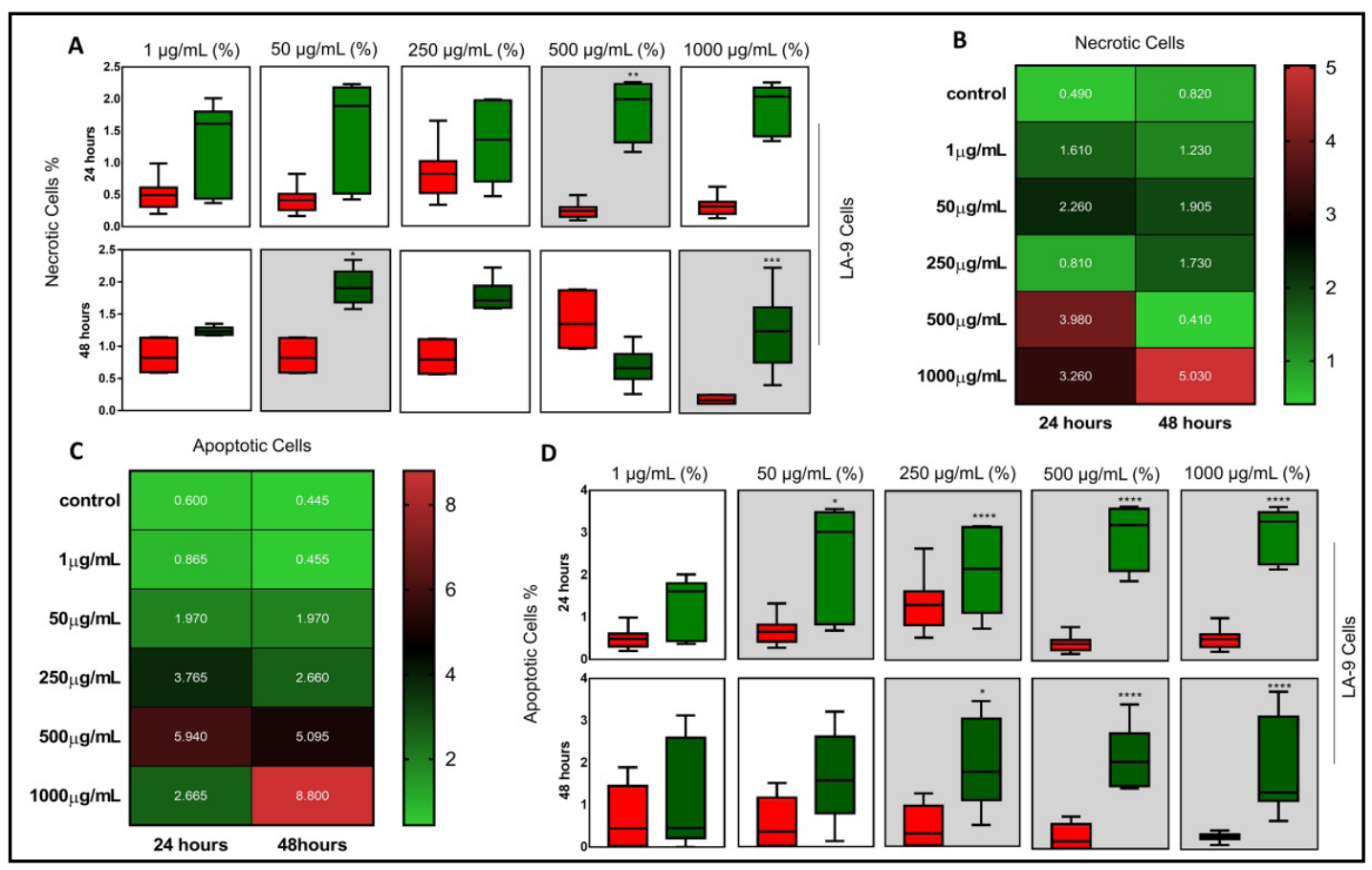

Fig. 7. Apoptosis / Necrosis in LA-9 cells after 24 and 48 hours of exposure to different concentrations of NP CB-EDA. (A, B) Volumes quantified in\% of apoptotic/necrotic cells compared to values quantified in the control group. (C, D) Correlation between apoptosis and necrosis of the groups analyzed in the periods of 24 and 48 hours. Green represents low \% necrosis / apoptosis expression and red represents high \% necrosis/ apoptosis expression. ${ }^{*} \mathrm{p}<0.05$ and vs Control $24 \mathrm{~h} . \& \mathrm{p}<0.05 \mathrm{vs} 48 \mathrm{~h}$ Control.

medium for the formation of the protein corona, depends on the concentration and size of the individual particles, this pronounced agglomeration for the NP CB-EDA $1000 \mu \mathrm{g} / \mathrm{ml}$ sample was expected [19]. This happens due to the change in the surface charge of the NP CB-EDA particles in the culture medium, which becomes more positive, due to the presence of multivalent cations that are a constituent part of the cell culture medium used (DMEM) [20]. It is important to note that this aggregation does not change the intrinsic characteristics of the NP CB-EDA nanoparticle in the culture medium, as well as their surface area [21].

The NP CB-EDA, based on its doses and physico-chemical characteristics, can modulate different cellular destinations, including cell viability, oxidative stress pathway such as ROS and RNS, some inflammatory factors, necrosis and apoptosis [7].

An important issue about the size of NP CB-EDA is its ability to easily penetrate through cell barriers, which can alter the integrity of the cell membrane, leading to the processes of apoptosis and/or necrosis. Our data obtained in 24 and 48 hours of exposure to NP CBEDA in fibroblasts LA-9 suggest a higher potential for formation of apoptotic cells than for necrotic cells, since this type of death occurs due to the reduction of cells, fragmentation of the internucleosomal DNA, vacuoles in the membrane, and formation of small vesicles called apoptotic bodies [22]. Apoptosis may be associated with an increase in ROS and its antioxidant capacity, which may generate oxidative stress. Redox regulation has numerous implications for cells, as it maintains the balance between formation and elimination of excess ROS [7].

The high levels of RNS may be related to the increase in TNF- $\alpha$, which can lead to mutations in the DNA, rupture of the membrane and induces cell signaling for apoptosis. The increase in TNF favors the production of IL-6 through the generation of active oxygen metabolites from the oxidative stress pathway ROS/RNS, triggering the entire process of cellular apoptosis [7]. 


\section{Cellular Physiology Cell Physiol Biochem 2021;55:364-377 \\ \begin{tabular}{ll|l} 
DOl: 10.33594/000000382 & $\begin{array}{l}\text { O } 2021 \text { The Author(s). Published by } \\
\text { Cell Physiol Biochem Press GmbH\&Co. KG }\end{array}$ \\
\cline { 2 - 4 }
\end{tabular} \\ de Almeida Rodolpho et al.: Apoptosis and Oxidative Stress Triggered by Carbon Black \\ Nanoparticle}

With all these factors, apoptosis is totally related to the excessive production of ROS, since the mitochondria of cells plays a fundamental role in homeostasis and the redox system, a fact that affects cell proliferation or cell death by apoptosis [10].

To maintain cell balance or stability in the medium, cell apoptosis becomes a key event for some physiological and pathological processes, with a significant impact on the pathogenesis of various diseases. According to [11-13], NPs with carbon structures induce apoptosis in different cell types.

We observed that the results of this study may be correlated with the oxidative stress pathways, with the high levels of ROS/RNS produced by the NP CB-EDA, at 24 and 48 hours of exposure in fibroblasts LA-9. It is already clarified in the literature that when the production of ROS is exacerbated and exceeds the limit of the cells' capacity for antioxidant defenses, proteins and lipids are totally damaged, which can lead to a pathophysiological condition and to apoptosis [23]. Studies have shown the increase in the expression of ROS in A549 cells (human lung carcinoma) exposed to carbon nanotubes. In 24 hours, there was an increase in ROS levels at concentrations of $50 \mu \mathrm{g} / \mathrm{mL}$ and $100 \mu \mathrm{g} / \mathrm{mL}$. After 48 hours, this increase occurred in the concentrations of $128 \mu \mathrm{g} / \mathrm{mL}$ and $256 \mu \mathrm{g} / \mathrm{mL}$. The increase in ROS levels is related to the production of nitric oxide (or NO), produced in the cytosol or mitochondria $[21,22]$.

In the present study, the production of RNS shows characteristics similar to ROS, in which the 24 hours exposure showed higher induction when compared to the 48 hours In the study of [24] with induction of MWCNTs (Multi-walled carbon nanotubes) in RAW macrophages it was reported a significant increase in their highest concentration. Other studies [25] reported the importance of observing ROS/RNS levels, since in large quantities they can cause apoptosis.

Suggesting that there is an increase in the levels of the oxidative stress pathway when there is exposure of NP CB-EDA, it is important to correlate the beginning of the cellular response, since the nanoparticle can lead to a change in activation of conformational proteins that transmit the signals to the receptors. The production of TNF- $\alpha$ and IL- 6 was analyzed in the fibroblasts LA- 9 as indicator of inflammatory response. Both the production of TNF- $\alpha$ and IL-6 were significant after 48 hours of exposure to NP CB-EDA, which corroborates the study of [26], in which no significant increase in TNF- $\alpha$ was observed in macrophages exposed to carbon positively loaded for 24 hours. High levels of TNF- $\alpha$ can induce RNS activation, resulting in the generation of NO. The RNS can react with membrane lipids and can cause DNA mutations. In addition, it can induce lipid peroxidation and signal cell death by apoptosis [7].

It is worth mentioning that, when exposed to $1000 \mu \mathrm{g} / \mathrm{ml}$ concentration of NP CB-EDA, the macrophages produced a greater amount of IL-6. This fact can be important since IL- 6 is considered as a fundamental mediator in several stages of inflammation [27]. Secreted by fibroblasts, their concentration levels may be related to the acute phase suggesting an inflammatory response and toxic potential for cells [28]. IL-6 can induce the oxidative stress pathway of ROS/RNS through the generation of active oxygen metabolites, produced after stimulation with TNF- $\alpha$, triggering the entire process of cell apoptosis [8].

The immune response may have been triggered from the release of LDH from cells exposed to NP CB-EDA, which means that its causes cell damage due to toxicity. This can be explained by the number of electrons that are relocated on the surface of the nanoparticle carbon nanotubes (CNTs). Fewer defects in CNTs result in many electrons being relocated which can generate hydrophobicity causing damage to lipid membranes [25]. In our study, LDH was released in fibroblasts LA-9 in both 24 and 48 hours when exposed to NP CB-EDA in the highest concentrations of 500 and $1000 \mu \mathrm{g} / \mathrm{ml}$.

The correlation of the data begins with MTT assays suggesting a decrease in cell viability in the tested times of 24 and 48 hours in fibroblasts LA- 9 fibroblast. The MTT assay data showed that in the two times observed (24 and 48 hours) the NP CB-EDA significantly inhibited the viability of the cells exposure to $250 \mu \mathrm{g} / \mathrm{ml}, 500 \mu \mathrm{g} / \mathrm{ml}$ and $1000 \mu \mathrm{g} / \mathrm{ml}$. The studies by $[26,30]$, with A549 and 3T3 cells, showed that with exposure to carbon 


\section{Cellular Physiology Cell Physiol Biochem 2021;55:364-377

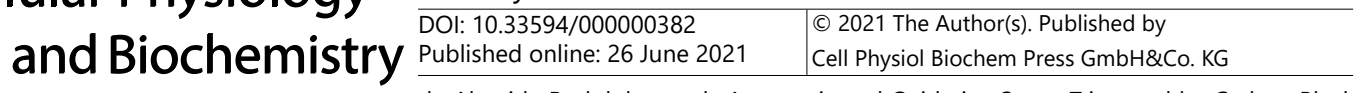 \\ de Almeida Rodolpho et al.: Apoptosis and Oxidative Stress Triggered by Carbon Black Nanoparticle}

black (CB) for 24 hours, there was a reduction in cell viability in the highest concentrations when compared to the control group. The results of [29], reported that in longer exposure times to CB there was a reduction in A549 cell viability by up to $40 \%$ in a dose-dependent response; these data corroborate our findings, to confirm the cytotoxicity observed by the MTT method [30].

Our results showed a reduction in cell viability at the two periods analyzed, at concentrations of $250 \mu \mathrm{g} / \mathrm{ml}$ and $1000 \mu \mathrm{g} / \mathrm{ml}$ of NP CB-EDA. There were observed reductions in the number of colonies and in the quantification obtained [31]. Therefore, it is possible to perceive that the highest concentrations of NP CB-EDA, when in contact with fibroblasts LA-9, seem to induce the oxidative stress pathway such as ROS and RNS, leading to an inflammatory response of IL- 6 and TNF- $\alpha$ and affecting integrity cell membrane, causing decreased in cell viability, and apoptosis/necrosis, showing a possible cytotoxic effect.

\section{Conclusion}

The results presented here show a cytotoxic potential of NP CB-EDA in murine fibroblasts LA-9, being dependent on the concentration. In general, there was a reduction in cell viability, damage to the cell membrane, a decrease in proliferative capacity, an increase in reactive oxygen and nitrogen species, an inflammatory profile leading to an increase in apoptotic cells in the exposure periods of 24 and 48 hours. These analyzes are extremely important, as this nanoparticle was synthesized for use in industry, which makes it able to circulate in the environment and in contact with organisms, it can cause irreparable damages.

\section{Acknowledgements}

The authors would like to thank Dra. Márcia Regina Cominetti (Department of Gerontology, Federal University of São Carlos - UFSCar. This work was supported by PETROBRAS /Project: Proc. No 2017/00010-7.

\section{Author Contributions}

Development of the study: J, K, B, P.

Study design: CS, F.

Data analysis: J, K, P, C, M.

Preparation of the article: J, K B, P, C, M.

Contribution of equipment and analysis: E, M.

Funding

This study was supported by PETROBRAS/Project: Proc. No 2017/00010-7.

Statement of Ethics

The authors have no conflicts of interest to declare.

\section{Disclosure Statement}

The authors have no conflicts of interest to declare. 


\section{Cellular Physiology Cell Physiol Biochem 2021;55:364-377 \begin{tabular}{l|l} 
and Bincl $10.33594 / 000000382$ & 2021 The Author(s). Published by
\end{tabular}

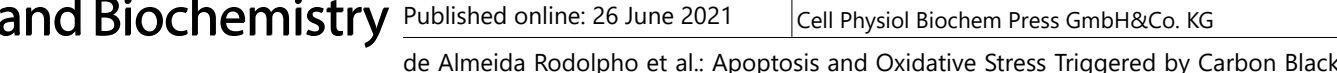 \\ Nanoparticle}

\section{References}

1 Khodabakhshi S, Fulvio PF, Andreoli E: Carbon black reborn: Structure and chemistry for renewable energy harnessing. Carbon 2020;162:604-649.

2 Lima MCFS, Zaida do Amparo S, Ribeiro H, Soares AL, Viana MM, Seara LM, Paniago RM, Silva GG, Caliman V: Aqueous suspensions of carbon black with ethylenediamine and polyacrylamide-modified surfaces: Applications for chemically enhanced oil recovery. Carbon 2016;109:290-299.

3 Lindner K, Ströbele M, Schlick S, Webering S, Jenckel A, Kopf J, Danov O, Sewald K, Buj C, Creutzenberg O, Tillmann T, Pohlmann G, Ernst H, Ziemann C, Hüttmann G, Heine H, Bockhorn H, Hansen T, König P, Fehrenbach H: Biological effects of carbon black nanoparticles are changed by surface coating with polycyclic aromatic hydrocarbons. Part Fibre Toxicol 2017;14:1-17.

4 Boland S, Hussain S, Baeza-Squiban A: Carbon black and titanium dioxide nanoparticles induce distinct molecular mechanisms of toxicity. Wiley Interdiscip Rev Nanomed Nanobiotechnol 2014;6:641-652.

5 Du J, Wang S, You H, Zhao X: Understanding the toxicity of carbon nanotubes in the environment is crucial to the control of nanomaterials in producing and processing and the assessment of health risk for human: A review. Environ Toxicol Pharmacol 2013;36:451-462.

6 Kinaret PAS, Scala G, Federico A, Sund J, Greco D: Carbon Nanomaterials Promote M1/M2 Macrophage Activation. Small 2020;16:e1907609.

7 Basuroy S, Tcheranova D, Bhattacharya S, Leffler CW, Parfenova H: Nox4 NADPH oxidase-derived reactive oxygen species, via endogenous carbon monoxide, promote survival of brain endothelial cells during TNF$\alpha$-induced apoptosis. Am J Physiol Cell Physiol 2011;300:C256-C265.

8 Nermin Özcan, Ceren Karaman, Necip Atar , Onur Karaman MLY: A Novel Molecularly Imprinting Biosensor Including Graphene Quantum Dots/Multi-Walled Carbon Nanotubes Composite for Interleukin-6 Detection and Electrochemical Biosensor Validation. ECS J Solid State Sci Technol 2020;9:121010.

9 Kaur S, Bansal Y, Kumar R, Bansal G: A panoramic review of IL-6: Structure, pathophysiological roles and inhibitors. Bioorg Med Chem 2020;28:115327.

10 Deweirdt J, Quignard JF, Lacomme S, Gontier E, Mornet S, Savineau JP, Marthan R, Guibert C, Baudrimont I: In vitro study of carbon black nanoparticles on human pulmonary artery endothelial cells: effects on calcium signaling and mitochondrial alterations. Arch Toxicol 2020;94:2331-2348.

11 Li Y, Yang M, Meng T, Niu Y, Dai Y, Zhang L, Zheng X, Jalava P, Dong G, Gao W, Zheng Y: Oxidative stress induced by ultrafine carbon black particles can elicit apoptosis in vivo and vitro. Sci Total Environ 2020;709:135802.

12 Niranjan R, Thakur AK: The toxicological mechanisms of environmental soot (black carbon) and carbon black: Focus on Oxidative stress and inflammatory pathways. Front Immunol 2017;8:1-20.

13 Samak DH, El-Sayed YS, Shaheen HM, El-Far AH, Onoda A, Abdel-Daim MM, Umezawa M: In-ovo exposed carbon black nanoparticles altered mRNA gene transcripts of antioxidants, proinflammatory and apoptotic pathways in the brain of chicken embryos. Chem Biol Interact 2018;295:133-139.

14 Saltzman BE: Colorimetric microdetermination of NO2 in the atmosphere. Anal Chem 1963;20:1949-1954.

15 Green LC, Wagner DA, Glogowski J, Skipper PL, Wishnok JS, Tannenbaum SR: Analysis of nitrate, nitrite, and [15N]nitrate in biological fluids. Anal Biochem 1982;126:131-138.

16 Wan CP, Myung E, Lau BHS: An automated micro-fluorometric assay for monitoring oxidative burst activity of phagocytes. Journal of Immunological Methods 1993;159:131-138.

17 Franken NAP, Rodermong HM, Stap J, Havemann J, van Bree C: Clonogenic assay of cells in vitro. Nat Protoc 2006;1:2315-2319.

18 Schindelin J, Arganda-Carreras I, Frise E, Kaynig V, Longair M, Pietzsch T, Preibisch S, Rueden C, Saalfeld S, Schmid B, Tinevez JY, White DJ, Hartenstein V, Eliceiri K, Tomancak P, Cardona A: Fiji: An open-source platform for biological-image analysis. Nat Methods 2012;9:676-682.

19 Cai X, Ramalingam R, Wong HS, Cheng J, Ajuh P, Cheng SH, Lam YW: Characterization of carbon nanotube protein corona by using quantitative proteomics. Nanomedicine 2013;9:583-593.

20 Hussain S, Boland S, Baeza-Squiban A, Hamel R, Thomassen LCJ, Martens JA, Billon-Galland MA, FleuryFeith J, Moisan F, Pairon JC, Marano F: Oxidative stress and proinflammatory effects of carbon black and titanium dioxide nanoparticles: Role of particle surface area and internalized amount. Toxicology 2009;260:142-149. 


\section{Cellular Physiology Cell Physiol Biochem 2021;55:364-377

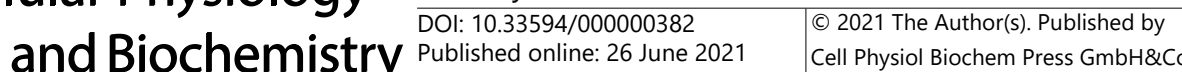 \\ de Almeida Rodolpho et al.: Apoptosis and Oxidative Stress Triggered by Carbon Black \\ Nanoparticle}

21 Phenrat T, Saleh N, Sirk K, Tilton RD, Lowry GV: Aggregation and sedimentation of aqueous nanoscale zerovalent iron dispersions. Environ Sci Technol 2007;41:284-290.

22 Elmore S: Apoptosis: A Review of Programmed Cell Death. Toxicol Pathol 2007;35:495-516.

23 Bartsch H, Nair J: New DNA-based biomarkers for oxidative stress and cancer chemoprevention studies. Eur J Cancer 2000;36:1229-1234.

24 Chen B, Liu Y, Song WM, Hayashi Y, Ding XC, Li WH: In vitro evaluation of cytotoxicity and oxidative stress induced by multiwalled carbon nanotubes in murine RAW 264.7 macrophages and human A549 Lung cells. Biomed Environ Sci 2011;24:593-601.

25 Hoshino K, Kashiwamura SI, Kuribayashi K, Kodama T, Tsujimura T, Nakanishi K, Matsuyama T, Takeda K, Akira S: The absence of interleukin I receptor-related T1/ST2 does not affect T helper cell type 2 development and its effector function. J Exp Med 1999;190:1541-1547.

26 Usman M, Zaheer Y, Younis MR, Demirdogen RE, Hussain SZ, Sarwar Y, et al.: The effect of surface charge on cellular uptake and inflammatory behavior of carbon dots. Colloids Interface Sci Commun 2020;35:100243.

27 Gallucci RM, Simeonova PP, Matheson JM, Kommineni C, Guriel JL, Sugawara T, Luster MI: Impaired cutaneous wound healing in interleukin-6-deficient and immunosuppressed mice. FASEB J 2000;14:25252531.

28 Garcia JBS, Issy AM, Sakata RK: Cytokines and anesthesia. Braz J Anesthesiol 2002;52:86-100.

29 Stone V, Shaw J, Brown DM, Macnee W, Faux SP, Donaldson K: The role of oxidative stress in the prolonged inhibitory effect of ultrafine carbon black on epithelial cell function. Toxicol In Vitro 1998;12:649-659.

30 Gellein K, Hoel S, Evje L, Syversen T: The colony formation assay as an indicator of carbon nanotube toxicity examined in three cell lines. Nanotoxicology 2009;3:215-221.

31 Louro H, Pinhão M, Santos J, Tavares A, Vital N, Silva MJ: Evaluation of the cytotoxic and genotoxic effects of benchmark multi-walled carbon nanotubes in relation to their physicochemical properties. Toxicol Lett 2016;262:123-134. 